\title{
Complex Determinants Influencing Inappropriate Antibiotic Use - A Systematic Review
}

\author{
Architha Aithal*, Abhishek Pradhan*, Shubhrajyotsna Aithal** \& A. R. Shabaraya* \\ *Srinivas College of Pharmacy, Valachil, Mangalore, Karnataka State, India \\ Email: aithalarchitha@gmail.com \\ **Dept. of Chemistry, College of Engineering \& Technology, Srinivas University, Mangalore, \\ India
}

Area/Section: Health Sciences.

Type of the Paper: Review Paper.

Type of Review: Peer Reviewed as per $|\mathrm{C}| \mathrm{O}|\mathrm{P}| \mathrm{E} \mid$ guidance.

Indexed in: OpenAIRE.

DOI: http://doi.org/10.5281/zenodo.4381270

Google Scholar Citation: $\underline{\text { IJHSP }}$

How to Cite this Paper:

Architha Aithal, Pradhan A. Aithal S., Shabaraya A. R., (2020). Complex Determinants Influencing Inappropriate Antibiotic Use - A Systematic Review. International Journal of Health Sciences and Pharmacy (IJHSP), 4(2), 34-53.

DOI: http://doi.org/10.5281/zenodo.4381270.

International Journal of Health Sciences and Pharmacy (IJHSP)

A Refereed International Journal of Srinivas University, India.

(C) With Author.

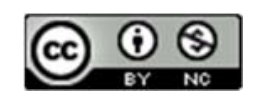

This work is licensed under a Creative Commons Attribution-Non Commercial 4.0 International License subject to proper citation to the publication source of the work.

Disclaimer: The scholarly papers as reviewed and published by the Srinivas Publications (S.P.), India are the views and opinions of their respective authors and are not the views or opinions of the SP. The SP disclaims of any harm or loss caused due to the published content to any party. 


\title{
Complex Determinants Influencing Inappropriate Antibiotic Use - A Systematic Review
}

\author{
Architha Aithal*, Abhishek Pradhan*, Shubhrajyotsna Aithal** \& A. R. Shabaraya* \\ *Srinivas College of Pharmacy, Valachil, Mangalore, Karnataka State, India \\ Email: aithalarchitha@gmail.com \\ **Dept. of Chemistry, College of Engineering \& Technology, Srinivas University, Mangalore, \\ India
}

\begin{abstract}
Antibiotic medicine is a kind of antimicrobial substance used to fight against the bacteria entered to the human body and hence is considered as a most important category of antibacterial agents to fight against bacterial infections either by killing them or inhibiting their growth. Antibiotic medications are widely used both for preventing and curing infections in human beings, animals, and agricultural plants but are not effective against viral infections, such as the common cold, flu, coughs, sore throats, etc. Even though antibiotics found their importance in fighting against bacterial infections, inappropriate use of them in humans, animals, and agricultural plants has considered as one of the reasons for developing antimicrobial resistance in them and which has several negative effects from different stakeholders' points of view. In this paper, through a systematic review, we made an attempt to study the determinant issues and complex affecting factors which influence the inappropriate antibiotic use and its consequences in controlling bacterial infections. The study focus on identifying and analyzing misuse of antibiotics including challenges involved in the inappropriate use of Antibiotics, the determinant factors influencing the inappropriate use of antibiotics through a systematic review, predict the determinant factors affecting the process of inappropriate use of antibiotics in an ideal situation which is the final goal of antibiotics research, developing a model by identifying the determinant factors which affects the decision of inappropriate use of antibiotics in society by various stakeholders. It also includes identifying the research gap which is the difference between current status and future anticipated optimistic ideal state and to develop research agendas based on identified research gap on inappropriate use of antibiotics and its effect on human health.
\end{abstract}

Keywords: Antibiotics, Inappropriate use, Humans and agriculture, Research agenda, Research gap, Antimicrobial resistance.

\section{INTRODUCTION:}

It is well known that diseases like food poisoning, gastritis, ulcers, gonorrhea, meningitis, etc. are caused by different types of bacteria. Every bacterium is a type of microorganism that looks a tiny structure of living thing that can be seen only with the help of a microscope. Many types of microorganisms like virus, fungi, and parasites are cause diseases to human beings. Some of the bacteria are considered as good bacteria which help various processes internal and external to the human body. The harmful bacteria cause infections and diseases and may emit toxins that may damage the body. It is also known that bacterial diseases are contagious and may result in many dangerous situations including blood poisoning, kidney failure, and toxic shock syndrome. The symptoms of bacterial diseases resemble viral diseases including fever. Bacterial diseases can be treated with antibiotics. Antibiotic medicine is a kind of antimicrobial substance used to fight against the bacteria entered to the human body and hence is considered as a most important category of antibacterial agents to fight against bacterial infections either by killing them or inhibiting their growth.

Antibiotic medications are widely used both for preventing and curing infections in human beings, animals, and agricultural plants but are not effective against viral infections, such as the common cold, flu, coughs, sore throats, corona, etc. Various types of antibiotics are available for treating bacteria borne diseases which are used either orally, intravenously, or by intramuscular injection 
depending on type and nature of the bacterial disease. Since many bacterial diseases are mild in symptoms initially, it is found that many patients are not found serious in following medication procedures systematically results in inappropriate use of antibiotics. Even though antibiotics found their importance in fighting against bacterial infections, inappropriate use of them in humans, animals, and agricultural plants has considered as one of the reasons for developing antimicrobial resistance in them and which has several negative effects from different stakeholders' points of view [1]. Such inappropriate use of antibiotics may be due to various reasons including mismatching of demand and supply of particular antibiotics in the retail sector or the economic condition of the user. This may also due to the involvement and advice of unqualified personnel at different stages. The use of such non-prescriptive antibiotics is more in some countries especially developing countries which resulted in the prevalence of antimicrobial resistance in such communities due to frequent use of non-prescriptive antibiotics [2]. Hence it is important to understand the determinant issues and the factors that affect the prescription of antibiotics by doctors and patient behavior on deciding and consuming antibiotics, which supports to choose or to develop pragmatic strategies that improve such use [3].

In this paper, through a systematic review, we made an attempt to study the determinant issues and complex affecting factors which influence the inappropriate antibiotic use and its consequences in controlling bacterial infections. The study focus on identifying and analyzing misuse of antibiotics including challenges involved in the inappropriate use of Antibiotics, the determinant factors influencing the inappropriate use of antibiotics through a systematic review, predict the determinant factors affecting the process of inappropriate use of antibiotics in an ideal situation which is the final goal of antibiotics research, developing a model by identifying the determinant factors which affects the decision of inappropriate use of antibiotics in society by various stakeholders. It also includes identifying the research gap which is the difference between current status and future anticipated optimistic ideal state and to develop a research agenda based on identified research gap on inappropriate use of antibiotics and its effect on human health.

\section{OBJECTIVES \& METHODOLOGY:}

The problem of inappropriate use of antibiotics either through doctor's advice or self-medication results in antimicrobial resistance (AMR) and it has associated pandemic economic and social dimensions both in developing and in low-income countries. Irrational consumption of antibiotics is a major factor for poor health conditions and prolonged disease time period. This study, therefore, aimed to investigate the determinant issues by identifying the affecting factors in deciding the consumption of antibiotic drugs prescribed by the doctors or by means of selfmedication in the society mainly of developing countries by considering their social, economic, and cultural factors. The objectives of the present review are :

(1) To know or evaluate the concept of antibiotic use.

(2) To learn the challenges involved in the inappropriate use of Antibiotics.

(3) To identify the determinant issues and affecting factors influencing the inappropriate use of antibiotics through a systematic review.

(4) To predict the factors affecting the process of inappropriate use of antibiotics in an ideal situation as the final goal of antibiotics research.

(5) To develop a model by identifying the determinant factors which affects the decision of inappropriate use of antibiotics in society by various stakeholders.

(6) To identify the research gap which is the difference between current status and future anticipated optimistic ideal state.

(7) To develop suitable research agendas based on identified research gap on inappropriate use of antibiotics and its effect on human health.

The methodology used in this review paper comprises of a collection of the existing scholarly research work during the last twenty years searched from Google Scholar indexed database. The primary data are referred directly from organizational authentic websites and the secondary data are collected from various scholarly articles and popular magazine articles \& edited books. The research agenda is identified by determining the research gap which is the difference between present status based on review and the anticipated future desired status in an optimistic situation called ideal status. Once the research gap is determined, a research agenda can be developed to decrease the gap towards the ideal situation. 


\section{REVIEW OF WORK DONE:}

\subsection{Based on Inappropriate Antibiotic Use:} Inappropriate use of antibiotics by the patients increases resistance, morbidity, and mortality. For bacterial infections, it is estimated that the major parts of the patients do not take medications based on prescriptions from qualified registered medical practitioners and at least half of the prescribed cases are inappropriate due to the fact that such antibiotics provide no benefit. This not only increases the prevalence antibiotic-resistance bacteria but also exposes patients to risk on adverse drug events, clostridium difficile infections and enhanced medication cost.

*Shively N. R. et al [4] in 2018 determined the most common antibiotics prescribed, the indications for which antibiotics were prescribed, and the rates of inappropriate usage of these antibiotics by primary care clinics. They found that $76 \%$ of reviewed prescriptions were inappropriate and concluded that there is an enormous opportunity to reduce inappropriate outpatient antibiotic prescriptions.

*The quality in healthcare system is continuously improved from many years by systematically identifying many determinant factors related to medication and healthcare service. These factors may be internal or external to the system. By considering determinant issues related to various stakeholders of the system it is possible to determine various factors affecting the system and a framework can be developed to analyse such system [5-6]. Flottorp et al [7] based on their systematic review developed a framework and taxonomies of determinant factors that prevent or enable improvements in medication in healthcare system which consists of a master checklist with the help of five worksheets.

*In 2019, Zanichelli V. et al [8] in their scholarly paper on patient related determinants of antibiotic use, identified 57 potential determinants categorized in seven domains as (1) guideline factors including clarity of recommendation, (2) individual health professional factors including awareness and familiarity with the recommendation or the skills needed to adhere, (3) patient factors including patient preferences, real or perceived needs and their demands, (4) professional interaction factors including opinions and communication among professionals or referral processes, (5) incentives and resources including availability of necessary resources, (6) capacity of organizational change including capable leadership, and (7) social, political, and legal factors including payer policies.

*Olayinka O. et al (2019) [9] investigated the patterns and determinants of antibiotic prescribing among doctors in a tertiary hospital in Nigeria as the first step to improve future antibiotic use in hospitals. As per their study 97\% prescribe antibiotics frequently, mostly based on clinical judgment and experience with rare laboratory supports. Factors of like (1) cost, (2) drug availability, and (3) information from pharmaceutical representatives influenced antibiotic prescribing. There were indications of nonexistence or nonfunctional institutional policies and guidelines regarding antimicrobial therapies. Based on the study they suggested the urgent need to institute evidence-based institutional policies and guidelines for improving antimicrobial use among hospitals in Nigeria.

* With the perception on Physicians still have inadequate knowledge and misconceptions about antibiotic prescribing, an extensive literature search from 1990 to 2014 on Knowledge, perceptions and prescribing behaviour are key to antibiotic prescribing is carried out by Md Rezal, R.S. et al during 2015 [10] resulted in nineteen articles in which eight in ambulatory care, seven in hospital settings and four in both, across all countries. Several factors influenced prescribing including (1) patients' expectations, (2) severity and duration of infections, (3) uncertainty over diagnosis, (4) potentially losing patients, and (5) influence of pharmaceutical companies were emerged from the study. The study concluded with the finding on inadequate knowledge of prescribing is prevalent among physicians. However, many physicians were interested in improving their antibiotic prescribing. Multifaceted interventions targeting all key stakeholders, including patients, are needed to improve future antibiotic prescribing.

\subsection{Based on Region wise Study :}

*Kotwani, A. et al [11] in 2010 explored the affecting factors that influence primary care physicians to prescribe antibiotics and to investigate possible interventions using focus group discussions in India. They identified 3 themes as (1) behavioural characteristics of doctors and patients, (2) laxity in regulation of prescribing, and dispensing antibiotics, and (3) intervention strategies to decrease misuse of, and resistance to, 
antibiotics. Important factors identified for antibiotic prescriptions by doctors were (a) diagnostic uncertainty, (b) perceived demand and expectation from the patients, (c) practice sustainability and financial considerations, (d) influence from medical representatives and (e) inadequate knowledge. Interventions like Continuing Medical Educations for doctors, awareness raising of patients, shared decision making and stricter rules and regulations were suggested to promote rational use of antibiotics in the community will be helpful to promote the appropriate use of antibiotics in the community.

*Oxford, J. et al [12] in 2013 studied the factors that influence on the level of inappropriate antibiotic prescribing in Europe. They identified and analyzed 4 factors as major causes of inappropriate antibiotic prescription as (1) significant external pressures to prescribe antibiotics like patient demand, (2) diagnostic uncertainty, (3) physicianpatient factors, and (4) the level of communication and co-operation between physicians, pharmacists, microbiologists, and specialists.

*Bharathiraja, R. et al [13] in 2005 determined the antibiotic prescription pattern and factors influencing on children receiving antibiotics for common illnesses. The study is conducted on 403 prescriptions given by 40 physicians at Chennai, India. Factors like postgraduate qualification, experience of physician, source and method of updating knowledge, inpatient practice setting and presence of fever are influenced prescription of antibiotics.

*Radyowijati, A. et al [14] published a review in 2003 on Improving antibiotic use in low-income countries which provides information on the factors that influence the use of antibiotics by health providers, dispensers and community members in low-income countries. They identified determinants related to antibiotic prescribing are as (1) Lack of knowledge, (2) Perceived patient demand, (3) Economic incentives, (4) Fear of bad clinical outcomes, and (5) Timely laboratory results. They also identified Antibiotic dispensing factors like (1) Lack of knowledge, (2) Perceived client demand, (3) Economic incentives, (4) Pressure of pharmaceutical promotion, and (5) Lack of regulation and enforcement. They also identified the determinants related to community antibiotic use such as (1) Folk beliefs on indications and effectiveness of antibiotics, (2) Knowledge on antibiotic use, (3) Economic considerations, (4) Marketing influences, etc.

*Hulscher, M. E. et al [15] analyzed factors influencing appropriate antibiotic use at four levels which include (1) patient knowledge and behavior, (2) Knowledge, opinion and behavior of medical professionals, (3) organization of care, (4) cultural and socio-economic context. They also suggested a national training programme at Netherlands on 'appropriate antibiotic use' for patient, professional and organizational-oriented activities.

*Van Buul, L. W. et al [16] conducted semistructured qualitative interviews with physicians and nursing staff in five nursing homes and two residential care homes in Netherlands during 2014 and developed a conceptual model and identified six categories of factors that can influence the antibiotic prescribing decision: (1) the clinical situation, (2) advance care plans, (3) utilization of diagnostic resources, (4) physicians' perceived risks, (5) influence of others, and (6) influence of the environment. They suggested that the model may be used as a practical tool in long-term care facilities to identify local factors potentially leading to inappropriate prescribing, and to subsequently intervene at the level of those factors to promote appropriate antibiotic prescribing.

*Reynolds L. e al [17] during 2009 made a qualitative study to assess knowledge, attitudes, and practices in relation to the use of antibiotics in China which has very high rates of antibiotic resistance and a health care system that provides strong incentives for over-prescribing. They used semi-structured interviews with patients and health workers and focus group discussion methods on factors related to (1) knowledge, (2) attitudes, and (3) practices in relation to the use of antibiotics.

*Sahoo K. C. et al [18] from India studied the influence of environmental factors on antibiotic use and resistance development in bacteria by exploring the perceptions of healthcare providers on antibiotic use and resistance development in relation to environmental factors i.e. physical, natural, social and behavioural factors using qualitative interviews. The factors like (1) changes in the natural and physical environment, (i.e. climate variability, pollution, physiography and population growth), (2) the socioeconomic environment affecting health-seeking behavior and noncompliance with medication, (3) a lack of 
healthcare facilities and poor professional attitudes, and (4) ineffective law enforcement regarding medicine dispensing and disposal. The study suggested a need for information, education, dissemination and proper implementation and enforcement of legislation at all levels of the drug delivery and disposal system in order to improve antibiotic use and prevent pharmaceutical contamination of the environment.

*Filippini, M. et al (2006) [19] studied socioeconomic determinants of antibiotic consumption in Switzerland. In their model they considered the factors related to per capita income, antibiotic price, the density of medical practices, demographic, cultural and educational factors.

* Masiero, G. et al [20] (2010) studied the impact of socioeconomic determinants and the role played by information about bacterial resistance. The study concluded that confirms that socioeconomic factors should be taken into account while explaining differences in outpatient antibiotic use across countries. The impact of supply-side factors and incentives attached to payment schemes for physicians need to be considered in government interventions to reduce inequalities and improve effectiveness in antibiotic utilization.

*Chan Y. Y. et al (2019) [21] identified determinants of antibiotic prescriptions in an emergency department using nine physicians with a good distribution of age, experience, and place of training. The six key themes emerged as determinants influencing the optimum clinical management include : (1) reliance on clinical knowledge and judgement, (2) patient-related factors, (3) patient-physician relationship factors, (4) perceived practice norms, (5) policies and treatment guidelines, and (6) patient education and awareness. The study concluded with the understanding that organizational practice norms strongly influenced antibiotic prescribing decisions by physicians, who can be swayed by time pressures and patient demands. Clinical decision support tools, hospital guidelines and patient education targeting at individual, interpersonal and community levels could reduce unnecessary antibiotic use.

Based on the review of the above papers it is possible to segregate the affecting factors on inappropriate antibiotic use and self-medication under following four broad determinant issues.

(1) Patient related issues like education, attitude, cultural background, belief, demography, environment, etc.

(2) Doctors related issues like attitude, knowledge, communication ability, decision ability, experience, seriousness, availability, environment, etc.

(3) Medical regulatory issues of the country like Country medical \& regulatory policy, Implementation aspects of the policy, medical and drug distribution and pricing policies, etc.

(4) Social \& Economic Issues of the country like access to antibiotic treatment, affordability, government or employers support, etc.

\section{OTHER RELATED WORKS:}

The review is also focused on other related areas like self-medication using antibiotics, inappropriate usage of antibiotics, and antimicrobial resistance. Some of the important scholarly papers published in these areas and the research focus are depicted along with the reference papers in the following table 1 .

\subsection{Self-medicated Antibiotics:}

Self-medication involves the use of antibiotic drugs to treat self-diagnosed illnesses by a patient or continued use of old drugs previously used for chronic diseases or symptoms. Self-medication may lead to the use of old medicine, sharing of medicines with relatives, friends, or family members. In developing countries, especially in villages, self-medication practices are common in patients, healthcare workers, and even doctors. 
Table 1 : Some of related scholarly work with their focus on self-medicated antibiotics

\begin{tabular}{|c|c|c|c|}
\hline S. No. & Topic & Focus & Reference \\
\hline 1 & $\begin{array}{l}\text { Self-medication } \\
\text { with antibiotics }\end{array}$ & $\begin{array}{l}\text { Self-medication with antibiotics \& evaluate } \\
\text { the factors associated with antibiotic misuse }\end{array}$ & $\begin{array}{l}\text { Al-Azzam, S. et al. } \\
(2007)[22]\end{array}$ \\
\hline 2 & $\begin{array}{l}\text { Self-medication } \\
\text { with antibiotics and } \\
\text { antimalarials }\end{array}$ & $\begin{array}{l}\text { Self-medication with antibiotics and } \\
\text { antimalarials \& evaluate factors associated } \\
\text { with self medication }\end{array}$ & $\begin{array}{l}\text { Awad, A. et al. (2005) } \\
\text { [23] }\end{array}$ \\
\hline 3 & $\begin{array}{l}\text { Self-medication } \\
\text { with antibiotics }\end{array}$ & $\begin{array}{l}\text { To determine whether antibiotics are used for } \\
\text { self-medication in southern Spain, a region } \\
\text { belonging to European Union }\end{array}$ & $\begin{array}{l}\text { Väänänen, M. H. et al. } \\
\text { (2006) [24] }\end{array}$ \\
\hline 4 & $\begin{array}{l}\text { Self-medication } \\
\text { with antibiotics }\end{array}$ & $\begin{array}{l}\text { Study of self-medication with antibiotics and } \\
\text { their sources of acquisition in Lithuania }\end{array}$ & $\begin{array}{l}\text { Berzanskyte, A. } \\
\text { Berzanskyte, A., et al. } \\
\text { (2006) [25] }\end{array}$ \\
\hline 5 & $\begin{array}{l}\text { Antibiotics self- } \\
\text { medication }\end{array}$ & $\begin{array}{l}\text { To evaluate the knowledge and behavior } \\
\text { toward antibiotic self-medication among } \\
\text { medical and non-medical university students } \\
\text { in Iran }\end{array}$ & $\begin{array}{l}\text { Sarahroodi, S. et al. } \\
(2010)[26]\end{array}$ \\
\hline 6 & $\begin{array}{l}\text { Self-medication } \\
\text { with antibiotics }\end{array}$ & $\begin{array}{l}\text { To study was to estimate the prevalence of } \\
\text { self-medication with antibiotics in } \mathrm{Abu} \\
\text { Dhabi }\end{array}$ & $\begin{array}{l}\text { Abasaeed, A. et al. } \\
(2009)[27]\end{array}$ \\
\hline 7 & $\begin{array}{l}\text { Family self- } \\
\text { medication and } \\
\text { antibiotics abuse }\end{array}$ & $\begin{array}{l}\text { To identify the determinants of self- } \\
\text { medication and antibiotic abuse in children } \\
\text { in Hefei City, China }\end{array}$ & $\begin{array}{l}\text { Bi, P. et al. }(2,000) \\
{[28]}\end{array}$ \\
\hline 8 & $\begin{array}{l}\text { Assessment of self- } \\
\text { medication of } \\
\text { antibiotics }\end{array}$ & $\begin{array}{l}\text { To assess the extent of self-medication } \\
\text { with antibiotics (SMA) in a Jordanian } \\
\text { population, and to evaluate the } \\
\text { sociodemographic factors affecting this } \\
\text { behaviour }\end{array}$ & $\begin{array}{l}\text { Sawair, F. A. et al. } \\
\text { (2009) [29] }\end{array}$ \\
\hline 9 & $\begin{array}{l}\text { Self-medication } \\
\text { with antibiotics in } \\
\text { rural population }\end{array}$ & $\begin{array}{l}\text { To estimate the use of antibiotics without } \\
\text { medical prescription in rural population of } \\
\text { primary care industry in Greece }\end{array}$ & $\begin{array}{l}\text { Skliros, E. et al. (2010) } \\
{[30]}\end{array}$ \\
\hline 10 & $\begin{array}{l}\text { Self medication } \\
\text { with antibiotics }\end{array}$ & $\begin{array}{l}\text { The study investigated the period prevalence, } \\
\text { patterns of use, and socio-demographic } \\
\text { factors associated with self medication with } \\
\text { antibiotics in Indonesia }\end{array}$ & $\begin{array}{l}\text { Widayati, A. et al. } \\
\text { (2011) [31] }\end{array}$ \\
\hline 11 & $\begin{array}{l}\text { Self-medication } \\
\text { practices with } \\
\text { antibiotics }\end{array}$ & $\begin{array}{l}\text { The study was carried out to estimate the } \\
\text { prevalence of self-medication with antibiotics } \\
\text { among tertiary level students in Accra } \\
\text { (Ghana) and evaluate factors associated with } \\
\text { the practice }\end{array}$ & $\begin{array}{l}\text { Donkor, E. S. et al. } \\
\text { (2012) [32] }\end{array}$ \\
\hline 12 & $\begin{array}{l}\text { Factors affecting } \\
\text { use of antibiotics } \\
\text { for self-medication }\end{array}$ & $\begin{array}{l}\text { The study explored Latino adults' experience } \\
\text { in treating common infections particularly in } \\
\text { regards to self-medication with antibiotics }\end{array}$ & $\begin{array}{l}\text { Mainous, A. G. et al. } \\
\text { (2008) [33] }\end{array}$ \\
\hline 13 & $\begin{array}{l}\text { Self-medication } \\
\text { practices with } \\
\text { antibiotics }\end{array}$ & $\begin{array}{l}\text { Investigates self-medication with antibiotics } \\
\text { behaviours and risk factors among university } \\
\text { students in China and explore relationship } \\
\text { between self-medication practices and } \\
\text { adverse drug events }\end{array}$ & $\begin{array}{l}\text { Zhu, X. et al. (2016) } \\
\text { [34] }\end{array}$ \\
\hline 14 & $\begin{array}{l}\text { Self-medication } \\
\text { and self- } \\
\text { prescription with } \\
\text { antibiotics }\end{array}$ & $\begin{array}{l}\text { Age, sex, and educational and income levels } \\
\text { were found the main determinants }\end{array}$ & $\begin{array}{l}\text { Alhomoud, F. et al. } \\
\text { (2017) [35] }\end{array}$ \\
\hline
\end{tabular}




\subsection{Inappropriate use of Antibiotics:}

It is believed that inappropriate antibiotic practices include lack of consultation with healthcare professionals, sales and purchase of antibiotics without prescription or following old prescriptions, purchase of home supply or online antibiotics without authentic quality check, sharing of antibiotics with other patients having similar symptoms, inadequate dosage regimens, and early cessation of the desired cycle of antibiotic therapy. Some of the scholarly papers focused on the inappropriate use of antibiotics are presented in table 2.

Table 2 : Some of related scholarly work with their focus on Inappropriate use

\begin{tabular}{|c|c|c|c|}
\hline S. No. & Topic & Focus & Reference \\
\hline 1 & $\begin{array}{l}\text { Determinants of } \\
\text { inappropriate use } \\
\text { of antibiotics }\end{array}$ & $\begin{array}{l}\text { Addressed the inappropriate use of } \\
\text { antibiotics by identifying determinants and } \\
\text { multifaceted corrective measures to improve } \\
\text { the system. }\end{array}$ & $\begin{array}{l}\text { Tangcharoensathien, } \mathrm{V} \text {. } \\
\text { et al. } 2018 \text { [36] }\end{array}$ \\
\hline 2 & $\begin{array}{l}\text { Factors affecting } \\
\text { the inappropriate } \\
\text { prescription of } \\
\text { antibiotics }\end{array}$ & $\begin{array}{l}\text { Study reveal factors that influence unduly } \\
\text { prescribing inappropriate antibiotics and the } \\
\text { emergence of antibiotic resistance in the } \\
\text { primary health care sector. }\end{array}$ & $\begin{array}{l}\text { Raspopović, K. et al. } \\
\text { (2016) [37] }\end{array}$ \\
\hline 3 & $\begin{array}{l}\text { Inappropriate use } \\
\text { of antibiotics in } \\
\text { children }\end{array}$ & $\begin{array}{l}\text { Inappropriate use of antibiotics in children is } \\
\text { a recognized issue and increased pressure } \\
\text { has generated widespread social concern }\end{array}$ & $\begin{array}{l}\text { Quan-Cheng, K. et al. } \\
\text { (2016) [38] }\end{array}$ \\
\hline 4 & $\begin{array}{l}\text { Medical and } \\
\text { psychosocial } \\
\text { factors associated } \\
\text { with antibiotic } \\
\text { prescription }\end{array}$ & $\begin{array}{l}\text { Factor analysis of antibiotic prescribing in } \\
\text { primary care. }\end{array}$ & $\begin{array}{l}\text { Lee, T. H. et al. (2017) } \\
\text { [39] }\end{array}$ \\
\hline 5 & $\begin{array}{l}\text { Inappropriate } \\
\text { antibiotic use in } \\
\text { soft tissue } \\
\text { infections }\end{array}$ & $\begin{array}{l}\text { Factors effecting on antibiotic use in soft } \\
\text { tissue infections. }\end{array}$ & $\begin{array}{l}\text { Paydar, K. Z. et al. } \\
\text { (2006) [40] }\end{array}$ \\
\hline 6 & $\begin{array}{l}\text { Predictors of } \\
\text { inappropriate } \\
\text { antibiotic } \\
\text { prescribing }\end{array}$ & $\begin{array}{l}\text { To assess whether physician knowledge, time } \\
\text { in practice, place of training and practice } \\
\text { volume explain the differences in antibiotic } \\
\text { prescribing among physicians }\end{array}$ & $\begin{array}{l}\text { Cadieux, G. et al. } \\
(2007)[41]\end{array}$ \\
\hline 7 & $\begin{array}{l}\text { Inappropriate } \\
\text { prescription of } \\
\text { antibiotics in } \\
\text { pediatric practice }\end{array}$ & $\begin{array}{l}\text { Calculates the frequency of antibiotic } \\
\text { prescriptions which do not follow best } \\
\text { practices in paediatrics primary care centres } \\
\text { and to examine the feelings of doctors and } \\
\text { parents about such prescription and } \\
\text { recommendation for national health } \\
\text { authorities. }\end{array}$ & $\begin{array}{l}\text { Marc, C. Marc, C. et al. } \\
\text { (2016) [42] }\end{array}$ \\
\hline 8 & $\begin{array}{l}\text { Inappropriate } \\
\text { antibiotic } \\
\text { prescription to } \\
\text { children }\end{array}$ & $\begin{array}{l}\text { To determine the rate of inappropriate } \\
\text { antibiotic prescription and to describe the } \\
\text { types of antibiotics prescribed by health } \\
\text { workers to children with an acute respiratory } \\
\text { infection. }\end{array}$ & $\begin{array}{l}\text { da Cunha, A. et al. } \\
(2003)[43]\end{array}$ \\
\hline 9 & $\begin{array}{l}\text { Purchase of } \\
\text { antibiotics without } \\
\text { prescription }\end{array}$ & $\begin{array}{l}\text { The purchase of antimicrobial agents in } \\
\text { drugstores without a prescription. }\end{array}$ & $\begin{array}{l}\text { Lansang, M. A. et al. } \\
\text { (1990) [44] }\end{array}$ \\
\hline
\end{tabular}




\subsection{Antimicrobial Resistance:}

Due to the ability of bacteria to develop resistance or opposition to action on antimicrobial agents, the treatment of bacterial infections is becoming increasingly complicated. To explain this resistance, antimicrobial agents are categorized as per their functional mechanisms which include, interface with cell wall synthesis, inhibition of protein synthesis, interface with nucleic acid synthesis, inhabitation of a metabolic pathway, and disruption of bacterial membrane structure. A given bacteria may intrinsically resist to one or more than one class of antimicrobial agents. It may also acquire resistance by mutation or via genes to enzymes that are capable to destroy the antibiotic drug or its actions especially reaching the intracellular targets. Sometimes, the resistance may lead to an alternative metabolic pathway which bypasses the action of the drug. The resultant problems include (1) common infections may become more difficult to treat and can continue as life threatening disease, (2) The patient may take longer, expensive treatment, (3) The resistant bacteria may spread to other associates including family members, friends, and even entire community. Some of the published scholarly papers related to antimicrobial resistance along with their focus are depicted in table 3.

Table 3 : Some of related scholarly work with their focus on Antimicrobial resistance

\begin{tabular}{|c|c|c|c|}
\hline S. No. & Topic & Focus & Reference \\
\hline 1 & $\begin{array}{l}\text { Challenges of drug } \\
\text { resistance }\end{array}$ & $\begin{array}{l}\text { Examined the factors that make drug } \\
\text { resistance a more difficult problem in poorer } \\
\text { countries. }\end{array}$ & $\begin{array}{l}\text { Laxminarayan, R. et } \\
\text { al. (2012) [45] }\end{array}$ \\
\hline 2 & $\begin{array}{l}\text { Bacteria resistance } \\
\text { to antibiotics }\end{array}$ & $\begin{array}{l}\text { The situations of how antibiotics resistance is } \\
\text { increased when antibiotics are underused, } \\
\text { overused or misused are discussed. }\end{array}$ & $\begin{array}{l}\text { Odonkor, S. T. et al. } \\
\text { (2011) [46] }\end{array}$ \\
\hline 3 & $\begin{array}{l}\text { Challenge of } \\
\text { antibiotic resistance }\end{array}$ & $\begin{array}{l}\text { Discussed how a concerted global response is } \\
\text { able to tackle rising rates of antibiotic } \\
\text { resistance. }\end{array}$ & $\begin{array}{l}\text { Cars, O., Högberg et } \\
\text { al. (2008) [47] }\end{array}$ \\
\hline 4 & $\begin{array}{l}\text { Appropriate } \\
\text { antibiotics use }\end{array}$ & $\begin{array}{l}\text { Various options including the development of } \\
\text { new antibiotics to treat resistant organisms, } \\
\text { vaccination to prevent infections, and } \\
\text { improved use of antibiotics are discussed. }\end{array}$ & $\begin{array}{l}\text { Lieberman, J. M. } \\
\text { (2003) [48] }\end{array}$ \\
\hline 5 & $\begin{array}{l}\text { Self-medication } \\
\text { and control } \\
\text { antibiotic resistance }\end{array}$ & $\begin{array}{l}\text { Inadequate dose, less duration of treatment, } \\
\text { and the often regarded as the irrational } \\
\text { drug use practices in self-medication practice }\end{array}$ & $\begin{array}{l}\text { Sunny, T. P. et al. } \\
\text { (2019) [49] }\end{array}$ \\
\hline 6 & $\begin{array}{l}\text { Self-medication } \\
\text { and antibiotic } \\
\text { resistance }\end{array}$ & $\begin{array}{l}\text { Explored the crisis of antibiotic resistance } \\
\text { and discover more about the current } \\
\text { challenges related to self-medication }\end{array}$ & $\begin{array}{l}\text { Rather, I. A. et al. } \\
(2017) \text { [50] }\end{array}$ \\
\hline 7 & $\begin{array}{l}\text { Mechanisms of } \\
\text { antimicrobial } \\
\text { resistance }\end{array}$ & $\begin{array}{l}\text { Illustrated the various ways of resistant } \\
\text { bacteria development based on reviews }\end{array}$ & $\begin{array}{l}\text { Tenover, F. C. (2006) } \\
{[51]}\end{array}$ \\
\hline 8 & $\begin{array}{l}\text { Relationship } \\
\text { between } \\
\text { antimicrobial use } \\
\text { and antimicrobial } \\
\text { resistance }\end{array}$ & $\begin{array}{l}\text { Used an ecologic study design to examine the } \\
\text { correlation between use of relevant antibiotics } \\
\text { in the outpatient setting with microbial } \\
\text { resistance }\end{array}$ & $\begin{array}{l}\text { Bronzwaer, S. L. et al. } \\
\text { (2002) [52] }\end{array}$ \\
\hline 9 & $\begin{array}{l}\text { Identification of } \\
\text { acquired } \\
\text { antimicrobial } \\
\text { resistance }\end{array}$ & $\begin{array}{l}\text { Identification } \\
\text { resistance genes is important for } \\
\text { understanding the underlying mechanisms } \\
\text { and the epidemiology of antimicrobial } \\
\text { resistance }\end{array}$ & $\begin{array}{l}\text { Zankari, E. et al. } \\
\text { (2012) [53] }\end{array}$ \\
\hline 10 & $\begin{array}{l}\text { Antimicrobial use } \\
\text { and its resistance }\end{array}$ & $\begin{array}{l}\text { Study designs to assess the effect of } \\
\text { antimicrobial resistance through different } \\
\text { pathways and their direct and indirect effects }\end{array}$ & $\begin{array}{l}\text { Lipsitch, M. et al. } \\
\text { (2002) [54] }\end{array}$ \\
\hline
\end{tabular}




\begin{tabular}{|c|c|c|c|}
\hline 11 & $\begin{array}{l}\text { Antimicrobial } \\
\text { resistance in } \\
\text { developing } \\
\text { countries }\end{array}$ & $\begin{array}{l}\text { Resistance to antimicrobial drugs is causing } \\
\text { increased mortality and morbidity from } \\
\text { infectious diseases }\end{array}$ & $\begin{array}{l}\text { Hart, C. A. et al. } \\
\text { (1998) [55] }\end{array}$ \\
\hline 12 & $\begin{array}{l}\text { Antimicrobial } \\
\text { resistance } \\
\text { determinants }\end{array}$ & $\begin{array}{l}\text { Described determinants likely to influence the } \\
\text { future epidemiology and health impact of } \\
\text { antimicrobial-resistant infections }\end{array}$ & $\begin{array}{l}\text { Harbarth, S. et al. } \\
\text { (2005) [56] }\end{array}$ \\
\hline 13 & $\begin{array}{l}\text { Antimicrobial } \\
\text { resistance in } \\
\text { hospital organisms }\end{array}$ & $\begin{array}{l}\text { Major influences on emergence of resistant } \\
\text { hospital bacteria include antimicrobial effects } \\
\text { in treated individuals, mechanisms for transfer } \\
\text { of resistance, and routes of transmission } \\
\text { within the hospital for bacteria }\end{array}$ & $\begin{array}{l}\text { McGowan Jr, J. E. } \\
\text { (1983) [57] }\end{array}$ \\
\hline 14 & $\begin{array}{l}\text { Health and } \\
\text { economic impacts }\end{array}$ & $\begin{array}{l}\text { Comparison of the impacts of infections due } \\
\text { to antimicrobial-resistant bacteria with } \\
\text { those of infections due to antimicrobial- } \\
\text { susceptible strains of the same bacteria, data } \\
\text { were evaluated }\end{array}$ & $\begin{array}{l}\text { Holmberg, S. D. et al. } \\
\text { (1987) [58] }\end{array}$ \\
\hline 15 & $\begin{array}{l}\text { Understanding the } \\
\text { mechanisms and } \\
\text { drivers }\end{array}$ & $\begin{array}{l}\text { Strategies to reduce antimicrobial resistance } \\
\text { by removing its selective pressure by } \\
\text { imparting a fitness cost }\end{array}$ & $\begin{array}{l}\text { Holmes, A. H. et al. } \\
\text { (2016) [59] }\end{array}$ \\
\hline 16 & $\begin{array}{l}\text { The threat of } \\
\text { antimicrobial } \\
\text { resistance }\end{array}$ & $\begin{array}{l}\text { The treats include inappropriate prescription } \\
\text { practices, inadequate patient education, } \\
\text { limited diagnostic facilities, unauthorized sale } \\
\text { of antimicrobials, lack of appropriate } \\
\text { functioning drug regulatory mechanisms, and } \\
\text { non-human use of antimicrobials }\end{array}$ & $\begin{array}{l}\text { Ayukekbong, J. A. et } \\
\text { al. (2017) [60] }\end{array}$ \\
\hline 17 & $\begin{array}{l}\text { Achieving global } \\
\text { targets }\end{array}$ & $\begin{array}{l}\text { Focused on (i) setting targets for decreasing } \\
\text { drug-resistant infections, (ii) suggesting } \\
\text { required finance for global action, and (iii) } \\
\text { proposing global health architecture }\end{array}$ & $\begin{array}{l}\text { Laxminarayan, R. et } \\
\text { al. (2016) [61] }\end{array}$ \\
\hline
\end{tabular}

\section{CHALLENGES OF INAPPROPRIATE} ANTIBIOTIC USE:

Based on systematic review and using the focus group discussion method [62,63], it is found that many people in society, both educated and uneducated, are using Antibiotics without proper prescriptions by qualified authorized doctors or pharmacists. Accordingly, some of the important challenges of the inappropriate use of antibiotic are listed in table 4 along with potential consequences and explained below:

(1) Self-medication: Overconfidence based on acquired knowledge or prediction, leads selfmedication. This is sometimes due to the intention of decreasing the cost for commonly available bacteria-based diseases like cold. Self-medication due to negligence on the disease leads to sometimes disaster.

(2) Prescription by unauthorized personnel: Use of antibacterial medicine prescribed by unauthorized people may also lead to disaster due to improper diagnosis or improper choice of the medicine. Choice of the unauthorized practitioner may be due to the intention to decrease the cost, failing to identify the qualified practitioner, nonavailability of qualified practitioners, etc.

(3) Unawareness of the consequences: In order to decrease the cost or to speed up the medication, or anxiety to get cured early, patients may go for inappropriate antibiotics use without foreseeing its consequences. Patients also make a wrong decision due to lack of information about, and poor awareness on the use of standard medicines prescribed by qualified professionals after proper diagnosis.

(4) Economic \& Social conditions: Many patients though suffering from bacterial diseases, have many reasons to go for inappropriate medication. This includes their economic and social background like poverty, non-availability of family members with them, local tradition and culture, social beliefs, pressure from parents or guides, many dependents and their health conditions, etc. In many developing countries the economic and social conditions play a vital role in self-medication 
which leads to inappropriate antibiotic use.

(5) Alternative local medicines: Many countries have alternative medicine systems which are used parallelly with the traditional medicine system. For example, Ayurveda, Homeopathy, Naturopathy, Traditional Chinese medicine, etc. These medicines could not prove their ability to cure bacterial infections and might be contributed to the development of antimicrobial resistance. These alternative medicine practices support unqualified professionals' involvement in the prescription of inappropriate local medicines.

(6) Importance of Time due to Busy life schedule: Time is an important resource and cannot be earned as per individual wish. Time is always a strategic resource at both the organizational and individual levels [64]. Patients due to their busy schedules and responsibilities in their families and working organization tend to choose an alternative strategy of self-medication.

(7) Lack of Government policies \& Regulations: Many countries are yet to develop or implement proper health policies and regulations to protect the public, promote access to care, and ensure that medical professionals maintain to high standards and receive the compensation that is their due.

(8) Lapse in Implementation of Government Policies: Many countries do not have strict monitoring systems and the existing systems are failed to maintain the regulations. For example, the lack of a strict surveillance system to monitor the implementation of government policies through regulatory bodies is visible in developing countries. (9) Potential substandard medicine availability: Substandard medicines are pharmaceutical products that do not meet their quality standards and specifications. Such substandard medicine may cause harm to patients and fail to treat the diseases for which they were intended and may deliberately/fraudulently misrepresent their identity, composition or source. Unfortunately, in most of developing countries have access to such substandard drugs and is substantially affect antibiotic use for counter bacterial diseases.

Table 4: Challenges and potential consequences of the inappropriate use of antibiotic identified in this review

\begin{tabular}{|c|c|c|}
\hline S. No. & Challenges & Potential Consequences \\
\hline 1 & Self medication & $\begin{array}{l}\text { Wrong medicine and wrong dose, Inappropriate medication, } \\
\text { Uncontrolled spread of bacterial disease leading to } \\
\text { unrepairable health conditions, Increase in antimicrobial } \\
\text { resistance, etc. }\end{array}$ \\
\hline 2 & $\begin{array}{l}\text { Prescription by unauthorized } \\
\text { personnel }\end{array}$ & $\begin{array}{l}\text { Wrong medicine usage, Side effects, Increased cost and } \\
\text { suffering time, New health problems, Unanticipated injury } \\
\text { and even death, etc. }\end{array}$ \\
\hline 3 & $\begin{array}{l}\text { Unawareness of the } \\
\text { consequences }\end{array}$ & $\begin{array}{l}\text { Leading to longer period of suffering, Wrong medication, } \\
\text { Ending with disasters, Enhanced cost and recovery time, etc. }\end{array}$ \\
\hline 4 & Economic \& Social conditions & $\begin{array}{l}\text { Low awareness, Constraints on cost of medication, Social } \\
\text { evil, etc. }\end{array}$ \\
\hline 5 & Alternative local medicines & $\begin{array}{l}\text { Continued suffering, Prolonged cure, increased } \\
\text { antimicrobial resistance, Side effects, etc. }\end{array}$ \\
\hline 6 & $\begin{array}{l}\text { Importance of Time due to } \\
\text { Busy life schedule }\end{array}$ & $\begin{array}{l}\text { Negligence on appropriate medication, Reliance on } \\
\text { alternative medication, Short-cut methods, Total negligence } \\
\text { leading to disaster, etc. }\end{array}$ \\
\hline 7 & $\begin{array}{l}\text { Lack of Government policies \& } \\
\text { Regulations }\end{array}$ & $\begin{array}{l}\text { Wrong diagnosis, Inappropriate medication, Self- } \\
\text { medication, Alternative medication due to fear on cost of } \\
\text { regular medication, Failure to procedure to get help due to } \\
\text { lack of health agencies appointed by the Govt. or policies, } \\
\text { etc. }\end{array}$ \\
\hline 8 & $\begin{array}{l}\text { Lapse in Implementation of } \\
\text { Government Policies }\end{array}$ & $\begin{array}{l}\text { Failure to get support from govt and health service personnel, } \\
\text { Inappropriate medication, Self-medication, Low quality } \\
\text { health facilities in the country, More casualties, etc. }\end{array}$ \\
\hline 9 & $\begin{array}{l}\text { Potential substandard medicine } \\
\text { availability }\end{array}$ & $\begin{array}{l}\text { Use of alternative and counterfeit drugs, } \\
\text { Doubt on the ability of antibiotic use for counter bacterial } \\
\text { diseases, etc. }\end{array}$ \\
\hline
\end{tabular}

Further, based on focus group interaction [62-63] and the review of literature on antimicrobial resistance due to inappropriate use of antibiotics, the research objective is developed to find the 
determinant issues and factors affecting it and to identify various possible research agenda.

\section{CONCEPTUAL MODEL ON FACTORS AFFECTING THE INAPPROPRIATE USE OF ANTIBIOTICS:}

Our conceptual general model on inappropriate use of antibiotics based on the review on previous work and using Focus group method [62-63] proposes five determinant issues through following postulates which obviously do not need testing:

\section{Postulate 1:}

Inappropriate use of antibiotics depends on attitude of the patient.

Explanation:

Inappropriate use of antibiotics based on selfmedication depends on the attitude of the patient which is nothing but tendency of patient to react positively or negatively in a given situation. The attitude of the patient depends on his feelings at that time. The feeling of the patent depends on his emotions at that time. The emotion of a patient depends on his beliefs during his life long experience and the beliefs depends on his previous and present environment [65]. Thus, it can be argued that the attitude of a patient for selfmedication by inappropriate use of antibiotics depends on his environmental conditions including, intensity of disease, demographical conditions, geographical location, help from others, doctor's availability, financial conditions, education and awareness on the nature of disease, accessibility of hospital/medicine, etc. It also depends on views, opinion, and feelings of patient with regard to available antibiotics in the market.

\section{Postulate 2:}

Inappropriate use of antibiotics depends on the attitude of the doctor

Explanation:

Inappropriate use of antibiotics based on selfmedication depends on the approachability of a doctor or health practitioner and his attitude. The ability of doctor to diagnose the disease, the nature of interaction, and creating awareness about the situation decides the patients understanding and importance of undergoing systematic medication. The behavior of the doctor which depends on his attitude which is once again depends on his feelings, emotions, beliefs, and his past and present environment [65] decides the understandability of patient and acceptance of the suggested systematic medication. Further, the education level and knowledge of the doctor, the effectiveness of communication, availability of diagnostic facility at that time, and accessibility of treatment also plays an important role.

\section{Postulate 3:}

Inappropriate use of antibiotics depends on the government regulations related to drug use in the country.

Explanation:

Inappropriate use of antibiotics based on selfmedication depends on the government regulations and its implementation in a given country. The national policies on providing health facilities by the local government, the spread and acceptance of health insurance by the citizens, the awareness of handling health related situations in the education system of the country, the availability of substitutes based on cost and speed, etc. If government has strict measures to monitor the quality of drug distributions and implementation authorities, the use of low-quality medicines as substitutes can be eliminated. The nature and the discipline of people in a country depends on how they follow the government regulations systematically especially related to health regulations. It is researched that the government strategies to implement the specific health policy to reduce inappropriate antibiotic use is poor and failed to reach their objectives in low and middle -income countries.

\section{Postulate 4:}

Inappropriate use of antibiotics depends on the social aspects including culture and tradition of the society.

Explanation:

Inappropriate use of antibiotics based on selfmedication or self-decision on dose of the consumption of prescribed drugs depends on the social aspects like long time belief on such diseases in the community, alternative medicines availability, easy and effective solutions based on proven records on alternative medicine systems. Cultural and psychological factors influence the patient decision due to its relation with human behavior, perceptions, beliefs and emotions and have important implications on self medication or inappropriate use of antibiotics.

\section{Postulate 5:}

Inappropriate use of antibiotics depends on the economic status of the country.

Explanation:

Inappropriate use of antibiotics based on selfmedication depends on financial status of 
individuals and the economy of the country as a whole. The economically rich countries will have stringent rule in self-medications and inappropriate use of antibiotics. The financial situation of the patient and his family decides the nature of medication if country has no supporting policy. The quality of such medication provided by the country government influence heavily the decision of the patients for inappropriate medication.

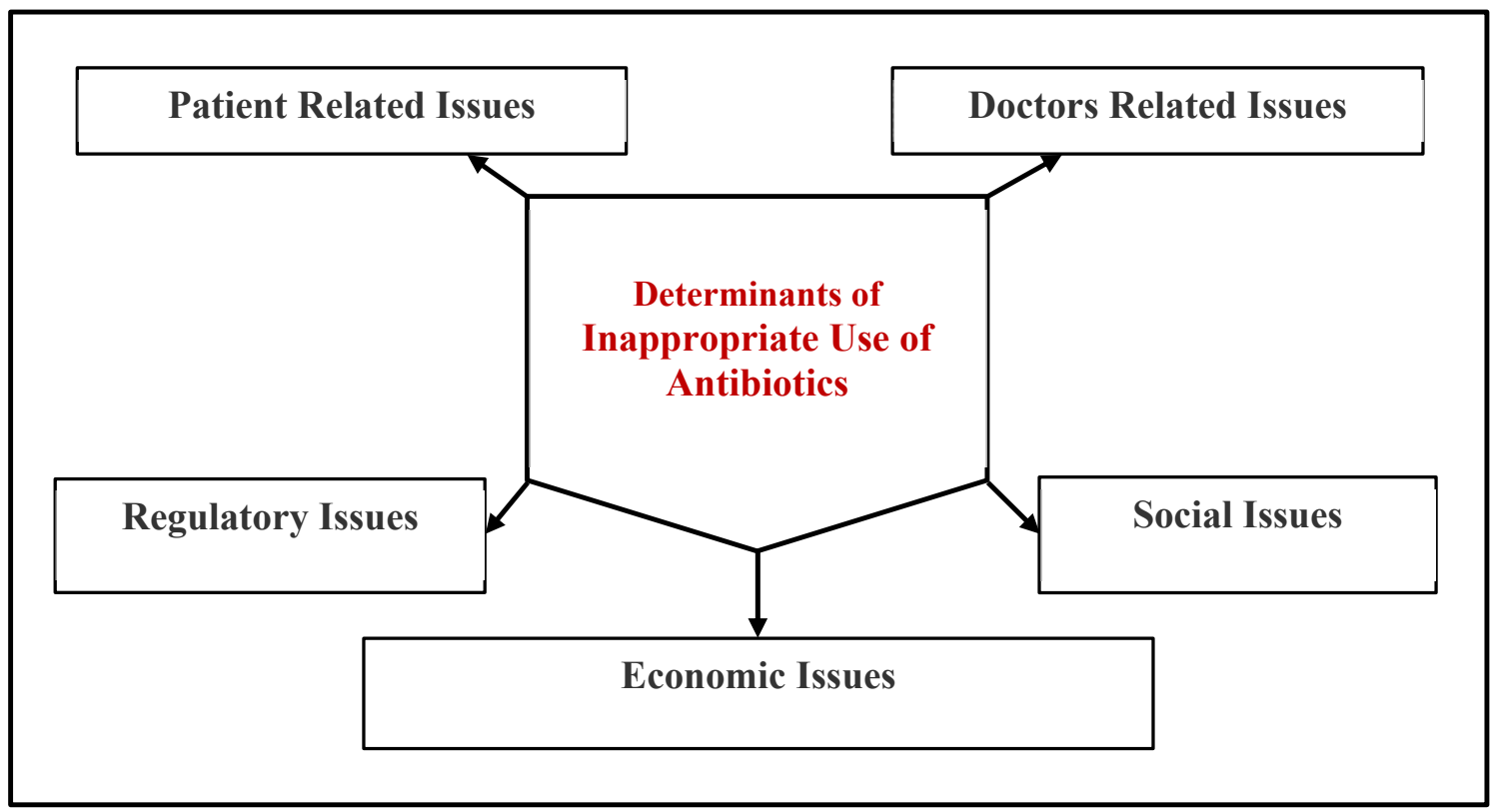

Fig. 1: Block diagram representation of the Conceptual General model on Inappropriate use of antibiotics

\subsection{Determinant Issues:}

\section{(1) Patient Related Issues:}

The following patient related issues are found to be dominant in deciding inappropriate use of antibiotics: (a) Education level, (b) Maturity status, (c) Potential consequences, (d) Attitude of handling situation, (e) Income and spending capability, (f) Ability to foresee the consequences, etc.

\section{(2) Doctors Related Issues:}

The following doctors related issues are found to be dominant in deciding inappropriate use of antibiotics: (a) Educational level, (b) Professional experience \& advancement, (c) Uncertainty over diagnosis, (d) Potentially losing patients, (e) Influence of pharmaceutical companies, (f) Availability and Accessibility, etc.

(3) Regulatory Issues:

The following regulatory issues are found to be dominant in deciding inappropriate use of antibiotics: (a) Health regulation, (b) Policy implementation status, (c) Punishments for faultiest, (d) Health support like insurance, (e) Free health awareness services to the children, etc.

(4) Social Issues:

The following social issues are found to be dominant in deciding inappropriate use of antibiotics: (a) Social status, (b) Community, Region, \& Caste, (c) Poverty, (d) Economic Deprivation, (e) Political Corruption, (f) Unemployment, (g) Availability of counterfeit drugs, etc.

(5) Economic Issues:

The following economy related issues are found to be dominant in deciding inappropriate use of antibiotics: (a) Poverty, (b) Health facilities, (c) Economy of the country, (d) Unemployment, (e) Family responsibility and condition, etc.

\subsection{Key Attributes:}

(1) Awareness about Consequence: Due to lack of education and awareness on the consequences of inappropriate use of drugs many patients neglect bacterial infected diseases.

(2) Speed of Recovery: With the anticipated expectation of speedy recovery from bacterial infected diseases and its painful symptoms, many patients choose for inappropriate use of drugs.

(3) Cost of Treatment: Patients from economically developing countries choose lowcost solutions to their infective diseases due to their inability to spending on costly branded drugs. 


\subsection{Affecting Factors:}

Based on the systematic review and focus group discussion, various affecting factors under determinant issues and key attributes are identified for inappropriate use of antibiotics are identified and categorized under four constructs Advantage, Benefit, Constraints, and Disadvantage as per ABCD Analysis Framework [5-6], [66-67] and listed in table 5 .

Table 5 : Factors affecting for Inappropriate use of antibiotics under ABCD constructs

\begin{tabular}{|c|c|c|c|c|c|c|}
\hline \multirow{2}{*}{$\begin{array}{l}\text { S. } \\
\text { No. }\end{array}$} & \multirow{2}{*}{$\begin{array}{l}\text { Determinant } \\
\text { Issues }\end{array}$} & \multirow{2}{*}{$\begin{array}{l}\text { Key } \\
\text { Elements }\end{array}$} & \multicolumn{4}{|c|}{ Affecting Factors } \\
\hline & & & Advantages & Benefits & Constraints & Disadvantages \\
\hline \multirow[t]{3}{*}{1} & \multirow[t]{3}{*}{$\begin{array}{l}\text { Patient } \\
\text { Related }\end{array}$} & Awareness & $\begin{array}{l}\text { Local } \\
\text { available } \\
\text { drugs }\end{array}$ & $\begin{array}{l}\text { Easy } \\
\text { availability }\end{array}$ & $\begin{array}{l}\text { Fear of self- } \\
\text { medication }\end{array}$ & $\begin{array}{ll}\text { Failure } & \text { of } \\
\text { alternative } & \\
\text { approach } & \end{array}$ \\
\hline & & Speed & Quick relief & $\begin{array}{l}\text { Temporary } \\
\text { recovery }\end{array}$ & $\begin{array}{l}\text { Resistance to } \\
\text { use } \\
\text { inappropriate } \\
\text { antibiotics }\end{array}$ & $\begin{array}{l}\text { Delay in } \\
\text { recovery }\end{array}$ \\
\hline & & Cost & $\begin{array}{ll}\text { Low cost due } \\
\text { to } & \text { low } \\
\text { fee/price } & \\
\end{array}$ & $\begin{array}{l}\text { Low } \\
\text { expenditure }\end{array}$ & $\begin{array}{l}\text { Unnecessary } \\
\text { expenditure }\end{array}$ & Increased cost \\
\hline \multirow[t]{3}{*}{2} & \multirow[t]{3}{*}{$\begin{array}{l}\text { Doctor } \\
\text { related }\end{array}$} & Awareness & $\begin{array}{l}\text { Wrong } \\
\text { diagnosis }\end{array}$ & $\begin{array}{l}\text { Wrong } \\
\text { medication }\end{array}$ & Less patients & Low earning \\
\hline & & Speed & $\begin{array}{l}\text { Quick } \\
\text { medication }\end{array}$ & $\begin{array}{l}\text { Temporary } \\
\text { relief }\end{array}$ & $\begin{array}{l}\text { Continuous } \\
\text { diagnosis }\end{array}$ & $\begin{array}{l}\text { Wrong } \\
\text { medication }\end{array}$ \\
\hline & & Cost & $\begin{array}{ll}\text { Low } & \text { fee } \\
\text { initially } & \end{array}$ & $\begin{array}{l}\text { Popular with } \\
\text { low-cost } \\
\text { brand }\end{array}$ & $\begin{array}{l}\text { Cost } \\
\text { enhancement } \\
\text { due } \\
\text { increased to } \\
\text { Antimicrobial } \\
\text { resistance }\end{array}$ & $\begin{array}{l}\text { Increased total } \\
\text { cost }\end{array}$ \\
\hline \multirow[t]{3}{*}{3} & \multirow[t]{3}{*}{$\begin{array}{l}\text { Regulatory } \\
\text { Related }\end{array}$} & Awareness & $\begin{array}{l}\text { Restricts self- } \\
\text { medication }\end{array}$ & $\begin{array}{l}\text { Reduced } \\
\text { inappropriate } \\
\text { use of } \\
\text { antibiotics }\end{array}$ & $\begin{array}{l}\text { Creating } \\
\text { awareness }\end{array}$ & $\begin{array}{l}\text { Difficulty in } \\
\text { changing self- } \\
\text { medication } \\
\text { attitude }\end{array}$ \\
\hline & & Speed & $\begin{array}{l}\text { Low-Controls } \\
\text { the self- } \\
\text { medication }\end{array}$ & $\begin{array}{l}\text { Controls the } \\
\text { Antimicrobial } \\
\text { resistance }\end{array}$ & $\begin{array}{l}\text { Implementation } \\
\text { of regulations } \\
\text { against self- } \\
\text { medication }\end{array}$ & $\begin{array}{l}\text { Hidden } \\
\text { inappropriate } \\
\text { use of } \\
\text { antibiotics } \\
\end{array}$ \\
\hline & & Cost & Education & $\begin{array}{l}\text { Knowing the } \\
\text { consequences }\end{array}$ & $\begin{array}{l}\text { Govt. } \\
\text { monitoring } \\
\text { system }\end{array}$ & $\begin{array}{l}\text { Difficulty in } \\
\text { inappropriate } \\
\text { use and control } \\
\text { of cost }\end{array}$ \\
\hline \multirow[t]{3}{*}{4} & \multirow[t]{3}{*}{$\begin{array}{l}\text { Social } \\
\text { related }\end{array}$} & Awareness & $\begin{array}{l}\text { Reduction in } \\
\text { self- } \\
\text { medication }\end{array}$ & Better health & $\begin{array}{l}\text { Deceases } \\
\text { inappropriate } \\
\text { use }\end{array}$ & $\begin{array}{ll}\text { Use } & \text { of } \\
\text { appropriate } \\
\text { antibiotics }\end{array}$ \\
\hline & & Speed & Low & Decrease & high & Increase \\
\hline & & Cost & Low cost & $\begin{array}{l}\text { Decreased } \\
\text { expenditure }\end{array}$ & $\begin{array}{l}\text { Continued } \\
\text { expenditure }\end{array}$ & $\begin{array}{l}\text { High cost for } \\
\text { socially } \\
\text { deprived people }\end{array}$ \\
\hline 5 & $\begin{array}{l}\text { Economic } \\
\text { related }\end{array}$ & Awareness & $\begin{array}{l}\text { Understanding } \\
\text { the economic } \\
\text { consequences }\end{array}$ & $\begin{array}{l}\text { Reduction in } \\
\text { inappropriate } \\
\text { usage of } \\
\text { antibiotics }\end{array}$ & $\begin{array}{l}\text { Self- } \\
\text { medication }\end{array}$ & $\begin{array}{ll}\text { Increase } & \text { in } \\
\text { antibiotic } & \\
\text { resistance } & \end{array}$ \\
\hline
\end{tabular}




\begin{tabular}{|l|l|l|l|l|l|}
\hline & Speed & Low & Early relief & Long time & $\begin{array}{l}\text { May convert } \\
\text { into a chronic } \\
\text { disease }\end{array}$ \\
\cline { 2 - 6 } & Cost & Less costly & $\begin{array}{l}\text { Less } \\
\text { expenditure }\end{array}$ & Poverty & $\begin{array}{l}\text { Increased total } \\
\text { cost }\end{array}$ \\
\hline
\end{tabular}

\section{RESEARCH GAP \& RESEARCH AGENDA FOR FURTHER RESEARCH:}

Ideally, the patients should consult the doctors for bacterial disease and should get a proper prescription for appropriate medication so that the patient's antimicrobial resistance will be very low. But the current research results based on this review show that there a considerable gap between ideal expectation of patient behaviour and current status of use of inappropriate antibiotics. This gap is called the research gap and the researchers can plan their research objective to fill this gap by researching the reasons for continued inappropriate use of antibiotics by patients in different countries. Due to various reasons leading to affecting factors under identified determinant issues, which are instigating inappropriate antibiotic use and hence increases antibiotic resistance which in turn increases the recovery time and total cost of medication.

In this study of identifying determinant issues and the factors affecting under used constructs offers various research opportunities as an appropriate research agenda. Some of the major and futuristic research agenda include:

(1) The critical constituent elements of each affecting factor under identified determinants issues can be determined under each construct Advantage, Benefit, Constraint, and Disadvantage. (2) Using the postulates of inappropriate use of antibiotics model developed in this review-based analysis, one can find the remedial solutions to control inappropriate antibiotic usage.

(3) A systematic study on antibiotic resistance appears in such patients who choose inappropriate antibiotic usage.

(4) A detailed study on various determinant issues in a given country and how the regulatory issues, social issues, and economic issues affect the patient decision on self-medication or inappropriate antibiotic use with or without the help of local doctors.

(5) Research is also due to knowing patients' attitude and behaviour towards managing bacteriabased diseases using systematic empirical study.

(6) Study on online marketing and supply of drugs without qualified doctors' prescription on selfmedication leading to inappropriate antibiotic use
[68].

(7) Study on the effect of alternative medicine used by patients and doctors from regional traditions in different countries to manage bacterial diseases and their contribution to antibiotic resistance.

(8) Case studies on government policies \& regulations, and implementation strategies and their effectiveness in managing inappropriate use of antibiotics in developed, developing, and underdeveloping countries.

(9) Study on the pattern of usage attitude of prescribed antibiotics by various tech-generations by considering Silent generation (those born during 1930-44), Boomers (those born during 1945-64), Generation X (those born between 1965-1979), generation Y (those born between 1980 to 1994), and generation $\mathrm{Z}$ (those born between 1995 to 2015) in developed and developing countries [69]. (10) An investigatory study on Root cause analysis [70] can be done to address the real cause of inappropriate medication including self-medication in different countries. The objective of root cause analysis is to find out the actual cause of an observed problem, defect, or failure with an intension to correct it by means of appropriate action.

(11) Not surprisingly, a new research agenda on people's attitudes and behaviour on the decision of using self-medication post COVID-19 due to enhanced health awareness in developing countries is also an attractive research topic in future days.

\section{CONCLUSION:}

Addressing the inappropriate use of antibiotics to control bacterial diseases among the different types of patients and identifying the factors affecting such decision of use is a challenge for many researchers in microorganism related disease control research. By knowing that many bacterial diseases are contagious and may result in dangerous situations including blood poisoning, kidney failure, and toxic shock syndrome, researchers set their objectives to study basic reasons and the consequences of inappropriate use of antibiotics. In this systematic review-based analysis, we have discussed the challenges involved in the inappropriate use of Antibiotics, identified the determinant issues and affecting 
factors influencing the inappropriate use of antibiotics through a systematic review, Predicted the factors affecting the process of inappropriate use of antibiotics in an ideal situation as the final goal of antibiotics research [71]. Based on the review and focus group discussion, we have developed a conceptual general model by identifying the determinant factors which affect the decision of inappropriate use of antibiotics in society by various stakeholders. Further, the research gap is identified as the difference between the current state and future anticipated optimistic ideal state. Based on the research gap, many research agendas are developed on the inappropriate use of antibiotics and its effect on human health.

\section{REFERENCES:}

[1] Tangcharoensathien, V., Chanvatik, S., Sommanustweechai, A. (2018). Complex determinants of inappropriate use of antibiotics. Bulletin of the World Health Organization, 96(2), 141-.

[2] Morgan, D. J., Okeke, I. N., Laxminarayan, R., Perencevich, E. N., Weisenberg, S. (2011). Non-prescription antimicrobial use worldwide: a systematic review. Lancet Infect Dis. 11(9), 692-701. DOI: http://dx.doi.org/10.1016/S14733099(11)70054-8 PMID: 21659004.

[3] Zanichelli, V., Tebano, G., Gyssens, I. C., Vlahović-Palčevski V., Monnier, A. A., Benic, M. S., Harbarth, S., Hulscher, M., Pulcini, C., Huttner, B. D. (2019). Patientrelated determinants of antibiotic use: a systematic review. Clinical microbiology and infection, 25(1), 48-53.

[4] Shively, N. R., Buehrle, D. J., Clancy, C. J., \& Decker, B. K. (2018). Prevalence of inappropriate antibiotic prescribing in primary care clinics within a Veterans Affairs health care system. Antimicrobial agents and chemotherapy, 62(8), e00337-18. DOI: 10.1128/AAC.00337-18.

[5] Aithal, P. S., Shailashree, V. T., Suresh Kumar, P. M. (2015). A New ABCD Technique to Analyze Business Models \& Concepts. International Journal of Management, IT and Engineering (IJMIE), 5(4), 409 - 423. DOI : http://doi.org/10.5281/zenodo.61652.

[6] Aithal, P. S. (2016). Study on ABCD Analysis Technique for Business Models, business strategies, Operating Concepts \& Business Systems. International Journal in Management and Social Science, 4(1), 98115. DOI: http://doi.org/10.5281/zenodo.161137.

[7] Flottorp, S. A., Oxman, A. D., Krause, J., Musila, N. R., Wensing, M., Godycki-Cwirko, M., ... \& Eccles, M. P. (2013). A checklist for identifying determinants of practice: a systematic review and synthesis of frameworks and taxonomies of factors that prevent or enable improvements in healthcare professional practice. Implementation Science, 8(35), $1-11 . \quad$ DOI: https://doi.org/10.1186/1748-5908-8-35.

[8] Zanichelli, V, Tebano, G, Gyssens, I. C., Vlahović-Palčevski, V, Monnier, A. A., Benic, M. S., Harbarth, S., Hulscher, M., Pulcini, C., Huttner B. D. (2019). Patientrelated determinants of antibiotic use: a systematic review. Clinical microbiology and infection. 25(1), 48-53.

[9] Olayinka O. Ogunleye, Joseph O. Fadare, Adesola F. Yinka-Ogunleye, Bene D. Anand Paramadhas \& Brian Godman (2019) Determinants of antibiotic prescribing among doctors in a Nigerian urban tertiary hospital, Hospital Practice, 47:1, 53-58, DOI: 10.1080/21548331.2018.1475997.

[10] Rabiatul Salmi Md Rezal, Mohamed Azmi Hassali, Alian A Alrasheedy, Fahad Saleem, Faridah Aryani Md Yusof \& Brian Godman (2015) Physicians' knowledge, perceptions and behaviour towards antibiotic prescribing: a systematic review of the literature. Expert Review of Anti-infective Therapy, 13(5), 665680. DOI: 10.1586/14787210.2015.1025057.

[11] Kotwani, A., Wattal, C., Katewa, S., Joshi, P. C., \& Holloway, K. (2010). Factors influencing primary care physicians to prescribe antibiotics in Delhi India. Family practice, 27(6), 684-690.

[12] Oxford, J., Goossens, H., Schedler, M., Sefton, A., Sessa, A., \& van der Velden, A. (2013). Factors influencing inappropriate antibiotic prescription in Europe. Education for Primary Care, 24(4), 291-293.

[13] Bharathiraja, R., Sridharan, S., Chelliah, L. R., Suresh, S., \& Senguttuvan, M. (2005). Factors affecting antibiotic prescribing pattern in pediatric practice. The Indian Journal of 
Pediatrics, 72(10), 877-879.

[14] Radyowijati, A., \& Haak, H. (2003). Improving antibiotic use in low-income countries: an overview of evidence on determinants. Social science \& medicine, 57(4), 733-744.

[15] Hulscher, M. E., van der Meer, J. W., \& Grol, R. P. (2010). Antibiotic use: how to improve it?. International Journal of Medical Microbiology, 300(6), 351-356.

[16] van Buul, L. W., van der Steen, J. T., Doncker, S. M., Achterberg, W. P., Schellevis, F. G., Veenhuizen, R. B., \& Hertogh, C. M. (2014). Factors influencing antibiotic prescribing in long-term care facilities: a qualitative in-depth study. BMC geriatrics, 14(1), 136.

[17] Reynolds, L., \& McKee, M. (2009). Factors influencing antibiotic prescribing in China: an exploratory analysis. Health policy, 90(1), 32$36 . \quad$ DOI https://doi.org/10.1016/j.healthpol.2008.09.00 2.

[18] Sahoo, K. C., Tamhankar, A. J., Johansson, E., \& Lundborg, C. S. (2010). Antibiotic use, resistance development and environmental factors: a qualitative study among healthcare professionals in Orissa, India. BMC Public health, 10(1), 629.

[19] Filippini, M., Masiero, G., \& Moschetti, K. (2006). Socioeconomic determinants of regional differences in outpatient antibiotic consumption: evidence from Switzerland. Health policy, 78(1), 77-92.

[20] Masiero, G., Filippini, M., Ferech, M., \& Goossens, H. (2010). Socioeconomic determinants of outpatient antibiotic use in Europe. International journal of public health, 55(5), 469-478.

[21] Chan, Y. Y., Bin Ibrahim, M. A., Wong, C. M., Ooi C. K., Chow, A. (2019). Determinants of antibiotic prescribing for upper respiratory tract infections in an emergency department with good primary care access: a qualitative analysis. Epidemiology and Infection, 147(e111), 1-7..

[22] Al-Azzam, S., Al-Husein, B., Alzoubi, F., Masadeh, M., \& Ali, M. (2007). Selfmedication with antibiotics in Jordanian population. International journal of occupational medicine and environmental health, 20(4), 373-380.

[23] Awad, A., Eltayeb, I., Matowe, L., \& Thalib, L. (2005). Self-medication with antibiotics and antimalarials in the community of Khartoum State, Sudan. $J$ Pharm Pharm Sci, 8(2), 326-331.

[24] Väänänen, M. H., Pietilä, K., \& Airaksinen, M. (2006). Self-medication with antibioticsdoes it really happen in Europe?. Health policy, 77(2), 166-171.

[25] Berzanskyte, A., Valinteliene, R., HaaijerRuskamp, F., Gurevicius, R., \& Grigoryan, L. (2006). Self-medication with antibiotics in Lithuania. International journal of occupational medicine and environmental health, 19(4), 246-253.

[26] Sarahroodi, S., Arzi, A., Sawalha, A. F., \& Ashtarinezhad, A. (2010). Antibiotics selfmedication among southern iranian university students. Int J Pharmacol, 6(1), 48-52.

[27] Abasaeed, A., Vlcek, J., Abuelkhair, M., \& Kubena, A. (2009). Self-medication with antibiotics by the community of Abu Dhabi Emirate, United Arab Emirates. The Journal of Infection in Developing Countries, 3(07), 491-497.

[28] Bi, P., Tong, S., \& Parton, K. A. (2000). Family self-medication and antibiotics abuse for children and juveniles in a Chinese city. Social science \& medicine, 50(10), 14451450 .

[29] Sawair, F. A., Baqain, Z. H., Karaky, A. A., \& Eid, R. A. (2009). Assessment of selfmedication of antibiotics in a Jordanian population. Medical Principles and Practice, 18(1), 21-25.

[30] Skliros, E., Merkouris, P., Papazafiropoulou, A., Gikas, A., Matzouranis, G., Papafragos, C., ... \& Sotiropoulos, A. (2010). Selfmedication with antibiotics in rural population in Greece: a cross-sectional multicenter study. BMC family practice, 11(58), 1-3.

[31] Widayati, A., Suryawati, S., De Crespigny, C., \& Hiller, J. E. (2011). Self medication with antibiotics in Yogyakarta City Indonesia: a cross sectional population-based survey. $B M C$ research notes, 4(1), 491-491.

[32] Donkor, E. S., Tetteh-Quarcoo, P. B., Nartey, P., \& Agyeman, I. O. (2012). Self-medication practices with antibiotics among tertiary level 
students in Accra, Ghana: a cross-sectional study. International journal of environmental research and public health, 9(10), 3519-3529.

[33] Mainous, A. G., Diaz, V. A., \& Carnemolla, M. (2008). Factors affecting Latino adults' use of antibiotics for self-medication. The Journal of the American Board of Family Medicine, 21(2), 128-134.

[34] Zhu, X., Pan, H., Yang, Z., Cui, B., Zhang, D., \& Ba-Thein, W. (2016). Self-medication practices with antibiotics among Chinese university students. Public health, 130(1), 7883.

[35] Alhomoud, F., Aljamea, Z., Almahasnah, R., Alkhalifah, K., Basalelah, L., \& Alhomoud, F. K. (2017). Self-medication and selfprescription with antibiotics in the Middle East - do they really happen? A systematic review of the prevalence, possible reasons, and outcomes. International journal of infectious diseases, 57(1), 3-12.

[36] Tangcharoensathien, V., Chanvatik, S., \& Sommanustweechai, A. (2018). Complex determinants of inappropriate use of antibiotics. Bulletin of the World Health Organization, 96(2), 141.

[37] Raspopović, K., Janković, S., \& Opančina, V. (2016). Factors affecting inappropriate prescription of antibiotics and the emergence of antibiotic resistance in patients in primary health care. Medicinski časopis, 50(3), 85-90.

[38] Quan-Cheng, K., Jian-Guo, W., Xiang-Hua, L., \& Zhen-Zhen, L. (2016). Inappropriate use of antibiotics in children in China. The Lancet, 387(10025), 1273-1274.

[39] Lee, T. H., Wong, J. G., Lye, D. C., Chen, M. I., Loh, V. W., Leo, Y. S., ... \& Chow, A. L. (2017). Medical and psychosocial factors associated with antibiotic prescribing in primary care: survey questionnaire and factor analysis. Br J Gen Pract, 67(656), e168-e177.

[40] Paydar, K. Z., Hansen, S. L., Charlebois, E. D., Harris, H. W., \& Young, D. M. (2006). Inappropriate antibiotic use in soft tissue infections. Archives of Surgery, 141(9), 850856.

[41] Cadieux, G., Tamblyn, R., Dauphinee, D., \& Libman, M. (2007). Predictors of inappropriate antibiotic prescribing among primary care physicians. Cmaj, 177(8), 877-
883.

[42] Marc, C., Vrignaud, B., Levieux, K., Robine, A., Guen, C. G. L., \& Launay, E. (2016). Inappropriate prescription of antibiotics in pediatric practice: analysis of the prescriptions in primary care. Journal of Child Health Care, 20(4), 530-536.

[43] da Cunha, A., Amaral, J., \& Silva, M. A. (2003). Inappropriate antibiotic prescription to children with acute respiratory infection in Brazil. Indian pediatrics, 40(1), 7-12.

[44] Lansang, M. A., Lucas-Aquino, R., Tupasi, T. E., Mina, V. S., Salazar, L. S., Juban, N., ... \& Kunin, C. M. (1990). Purchase of antibiotics without prescription in Manila, the Philippines. Inappropriate choices and doses. Journal of clinical epidemiology, 43(1), 61-67.

[45] Laxminarayan, R., \& Heymann, D. L. (2012). Challenges of drug resistance in the developing world. Bmj, 344, e1567.

[46] Odonkor, S. T., \& Addo, K. K. (2011). Bacteria resistance to antibiotics: recent trends and challenges. Int J Biol Med Res, 2(4), 1204-10.

[47] Cars, O., Högberg, L. D., Murray, M., Nordberg, O., Sivaraman, S., Lundborg, C. S., ... \& Tomson, G. (2008). Meeting the challenge of antibiotic resistance. Bmj, 337, a1438.

[48] Lieberman, J. M. (2003). Appropriate antibiotic use and why it is important: the challenges of bacterial resistance. The Pediatric infectious disease journal, 22(12), 1143-1151.

[49] Sunny, T. P., Jacob, R., Krishnakumar, K., \& Varghese, S. (2019). Self-medication: Is a serious challenge to control antibiotic resistance?. National Journal of Physiology, Pharmacy and Pharmacology, 9(9), 821-827.

[50] Rather, I. A., Kim, B. C., Bajpai, V. K., \& Park, Y. H. (2017). Self-medication and antibiotic resistance: Crisis, current challenges, and prevention. Saudi journal of biological sciences, 24(4), 808-812.

[51] Tenover, F. C. (2006). Mechanisms of antimicrobial resistance in bacteria. The American journal of medicine, 119(6), S3S10. 
[52] Bronzwaer, S. L., Cars, O., Buchholz, U., Mölstad, S., Goettsch, W., Veldhuijzen, I. K., ... \& Degener, J. E. (2002). The relationship between antimicrobial use and antimicrobial resistance in Europe. Emerging infectious diseases, 8(3), 278-282.

[53] Zankari, E., Hasman, H., Cosentino, S., Vestergaard, M., Rasmussen, S., Lund, O., ... \& Larsen, M. V. (2012). Identification of acquired antimicrobial resistance genes. Journal of antimicrobial chemotherapy, 67(11), 2640-2644.

[54] Lipsitch, M., \& Samore, M. H. (2002). Antimicrobial use and antimicrobial resistance: a population perspective. Emerging infectious diseases, 8(4), 347.

[55] Hart, C. A., \& Kariuki, S. (1998). Antimicrobial resistance in developing countries. Bmj, 317(7159), 647-650.

[56] Harbarth, S., \& Samore, M. H. (2005). Antimicrobial resistance determinants and future control. Emerging infectious diseases, 11(6), 794-801.

[57] McGowan Jr, J. E. (1983). Antimicrobial resistance in hospital organisms and its relation to antibiotic use. Reviews of infectious diseases, 5(6), 1033-1048.

[58] Holmberg, S. D., Solomon, S. L., \& Blake, P. A. (1987). Health and economic impacts of antimicrobial resistance. Reviews of infectious diseases, 9(6), 1065-1078.

[59] Holmes, A. H., Moore, L. S., Sundsfjord, A., Steinbakk, M., Regmi, S., Karkey, A., ... \& Piddock, L. J. (2016). Understanding the mechanisms and drivers of antimicrobial resistance. The Lancet, 387(10014), 176-187.

[60] Ayukekbong, J. A., Ntemgwa, M., \& Atabe, A. N. (2017). The threat of antimicrobial resistance in developing countries: causes and control strategies. Antimicrobial Resistance \& Infection Control, 6(47), 1-8.

[61] Laxminarayan, R., Sridhar, D., Blaser, M., Wang, M., \& Woolhouse, M. (2016). Achieving global targets for antimicrobial resistance. Science, 353(6302), 874-875.

[62] Aithal, P. S., \& Shubhrajyotsna Aithal, (2015). Ideal Technology Concept \& its Realization Opportunity using Nanotechnology, International Journal of Application or
Innovation in Engineering \& Management (IJAIEM), 4(2), $153-164 . \quad$ DOI: http://doi.org/10.5281/zenodo.61591.

[63] Aithal, P. S. \& Shubhrajyotsna Aithal (2018). The Concept \& Characteristics of Ideal Energy System and its Realization Constraints. International Journal of Applied Engineering and Management Letters (IJAEML), 2(2), 127-137.

DOI: https://doi.org/10.5281/zenodo.1487702.

[64] Suresh Kumar P. M. \& Aithal P. S. (2020). Time as a Strategic Resource in Management of Organizations. ICTACT Journal on Management Studies, 6(1), 1138-1143. DOI : http://doi.org/10.21917/ijms.2020.0158.

[65] Aithal, P. S., \& Aithal, Shubhrajyotsna. (2019). A New Attitude-Behaviour (AB) Theory for Organizational Leadership. International Journal of Management, Technology, and Social Sciences (IJMTS), 4(1), 83-97. DOI: http://doi.org/10.5281/zenodo.3248646.

[66] Aithal, P. S., Shailashree V. T. \& Suresh Kumar P. M. (2016). Analysis of ABC Model of Annual Research Productivity using ABCD Framework. International Journal of Current Research and Modern Education (IJCRME), l(1), 846-858. DOI http://doi.org/10.5281/zenodo.62022.

[67] Architha Aithal, and Aithal, P. S., (2017). ABCD Analysis of Task Shifting - An optimum Alternative Solution to Professional Healthcare Personnel Shortage. International Journal of Health Sciences and Pharmacy (IJHSP), $\quad$ 1(2), 36-51. DOI: http://dx.doi.org/10.5281/zenodo.1038975.

[68] Architha Aithal \& Shabaraya, A. R. (2018). Users Perspectives on Online Pharmacy Model. International Journal of Health Sciences and Pharmacy (IJHSP), 2(1), 29-36. DOI: http://dx.doi.org/10.5281/zenodo.1292790.

[69] Aithal P. S. \& Aithal Shubhrajyotsna (2020). Promoting Faculty and Student-Centered Research and Innovation based Excellence Model to Reimage Universities. International Journal of Management, Technology, and Social Sciences (IJMTS), 5(1), 24-41. DOI: http://doi.org/10.5281/zenodo.3702399.

[70] Nimisha Menon, Krishnananda K. Kamath, \& 
Shabaraya, A. R. (20167). Conducting root cause analysis and its implementation: A perspective. Manipal Journal of Pharmaceutical Sciences, 2(2), 21-25.

[71] Architha Aithal \& Aithal, P. S. (2018 October). The concept of Ideal Drug \& Its Realization Opportunity using present
Pharmaceutical Sciences Scenario. International Journal of Health Sciences and Pharmacy (IJHSP), 2(2), 11-26. DOI : http://doi.org/10.5281/zenodo.1469963. 